\title{
Thrombocytopenia: diagnosis with flow cytometry and antiplatelet antibodies
}

\author{
Plaquetopenias: diagnóstico usando citometria de fluxo e anticorpos antiplaquetas
}

\author{
João Carlos de Campos Guerra ${ }^{1}$, Ruth Hissae Kanayama², Sonia Tsukasa Nozawa², Márcia Regina Ioshida ${ }^{3}$, \\ Irina Yoko Takiri ${ }^{3}$, Robson José Lazaro ${ }^{3}$, Nelson Hamerschlak ${ }^{4}$, Luiz Gastão Mange Rosenfeld ${ }^{5}$, \\ Celso Carlos de Campos Guerra ${ }^{6 \dagger}$, Nydia Strachman Bacal ${ }^{2}$
}

\begin{abstract}
Objective: To identify antiplatelet antibodies by flow cytometry (direct method) in patients with thrombocytopenia. Methods: Between January 1997 and March 2004 a total of 15100 patients were referred to the Centro de Hematologia de São Paulo for hematological investigation of several diagnoses (anemia, leukopenia, thrombocytopenia, coagulation abnormalities, adenomegaly, leukemia and others). Of those, 1057 were referred because of thrombocytopenia and were divided into two groups: Group Idiopathic thrombocytopenic purpura, with no identifiable cause; and Group Other thrombocytopenia, which included low normal platelet counts cause to be established, hepatitis C and HIV infection, hypersplenism, EDTA-induced artifacts, laboratory error, and other causes. Flow cytometry immunophenotyping was done in 115 cases to identify platelet autoantibodies (direct method). Results: Of the total number of patients, 1057 (7\%) presented low platelet counts, 670 were females $(63.4 \%)$ and age range of one to 75 years. Of the 115 cases $(9.7 \%)$ submitted to immunophenotyping, the results were positive in $40 \%$ and the test was inconclusive in $5 \%$. Idiopathic thrombocytopenic purpura was found in $52 \%$ of patients, more often in women. Hepatitis C virus infection was found in $7 \%$ and HIV infection in $1 \%$. Low normal platelet counts were found in $17 \%$, laboratory errors in $6 \%$, and laboratory artifacts in $1 \%$ of cases. Platelet autoantibodies were found in $76.9 \%$ of all idiopathic thrombocytopenic purpura cases. It was negative in $83.3 \%$ of the low normal counts. Conclusion: antiplatelet autoantibodies when present help to diagnose idiopathic thrombocytopenic purpura. When absent, suggest other causes of thrombocytopenia.
\end{abstract}

Keywords: Flow cytometry; Blood platelets

\section{RESUMO}

Objetivo: Identificar anticorpos antiplaquetas por citometria de fluxo (método direto) em pacientes com plaquetopenia. Métodos: No período de Janeiro de 1997 a Março de 2004, foram encaminhados ao Centro de Hematologia de São Paulo 15.100 pacientes para investigação hematológica, com vários diagnósticos (anemia, leucopenia, plaquetopenia, alteração da coagulação, adenomegalias, leucemia e outros) dos quais 1.057 apresentavam plaquetopenia. Esses pacientes, conforme diagnóstico, foram separados em dois grupos: Grupo Púrpura Trombocitopênica Idiopática, quando não foi descoberta a etiologia da plaquetopenia; e Grupo Outra Trombocitopenia, que incluía faixa de normalidade a esclarecer, infecção pelo vírus da hepatite C, HIV, hiperesplenismo, artefato EDTA, erro laboratorial e outras. Em 115 casos, foi realizada imunofenotipagem, para identificação de anticorpo antiplaquetas (método direto), por citometria de fluxo. Resultados: Dos 1.057 casos (7\%) encaminhados por plaquetopenia, 670 casos $(63,4 \%)$ eram do sexo feminino. As idades variavam entre 1 e 75 anos. Dos 115 casos $(9,7 \%)$ em que foi realizada imunofenotipagem, houve positividade em $40 \%$ e o exame foi duvidoso em $5 \%$. A púrpura trombocitopênica idiopática foi encontrada em $52 \%$ dos casos, sendo mais frequente no sexo feminino, em crianças e adultos jovens. A prevalência do vírus da hepatite $C$ foi encontrada em $7 \%$ dos casos e HIV em $1 \%$ dos casos. Faixa de normalidade foi encontrada em $17 \%$; erro laboratorial em $6 \%$ e artefato laboratorial em $1 \%$ dos casos. Conclusão: 0 anticorpo antiplaquetas é um exame útil, quando positivo, para confirmar o diagnóstico de púrpura trombocitopênica idiopática e, quando negativo, sugere outras causas de trombocitopenia.

Descritores: Citometria de fluxo; Plaquetas

\footnotetext{
Study carried out at Hospital Israelita Albert Einstein - HIAE, São Paulo (SP), Brazil; Centro de Hematologia de São Paulo - CHSP, São Paulo (SP), Brazil.

${ }^{1}$ Hematology, Department of Clinical Pathology, Hospital Israelita Albert Einstein - HIAE, São Paulo (SP), Brazil.

${ }^{2}$ Division of Flow Cytometry, Department of Clinical Pathology, Hospital Israelita Albert Einstein - HIAE, São Paulo (SP), Brazil.

${ }^{3}$ Clinical Laboratory, Centro de Hematologia de São Paulo - CHSP - São Paulo (SP), Brazil.

${ }^{4}$ Hematology and Bone Marrow Transplantation, Hospital Israelita Albert Einstein - HIAE - São Paulo, Brazil.

${ }^{5}$ Diagnósticos da América S/A-DASA - São Paulo (SP), Brazil.

${ }^{6}$ In memoriam, Full Professor of Hematology, Universidade Federal de São Paulo - UNIFESP - São Paulo (SP), Brazil.

Corresponding author: João Carlos de Campos Guerra - Av. Albert Einstein, 627 - Morumbi - CEP 05651-901 - São Paulo (SP), Brasil - Tel.: (11) 2151 - 2430 - e-mail: jcguerra@einstein.br

Conflicts of interest: none

Received on: Aug 10, 2010 - Accepted on: Apr 16, 2011
} 


\section{INTRODUCTION}

Recent developments in medicine have made the complete blood count (CBC) a routine test for everybody. With modern cell counting devices, platelet counting has been routinely reported to physicians.

Hematologists today have patients who are referred to them because of abnormalities in the CBC (anemia, leucopenia and thrombocytopenia), mostly as laboratory findings. Thrombocytopenia is responsible for $9.1 \%$ of the cases first seen in the Centro de Hematologia de São Paulo (CHSP).

Thrombocytopenia classification is divided into low platelet production, increased platelet destruction and other causes $^{(1)}$ (Figure 1).

Pseudothrombocytopenia (PTCP) is a false laboratory phenomenon of low platelet counts (false thrombocytopenia), caused by in vitro platelet aggregation in the presence of platelet autoantibodies and anticoagulants, the most common being EDTA. Although a rare laboratory finding $(0.1 \%$ of the cases), PTCP has been on the rise since the advent of electronic cell counters. Failure in recognizing these changes may cause misdiagnoses and inadequate treatment ${ }^{(2-4)}$.

\section{OBJECTIVE}

To identify antiplatelet autoantibodies by flow cytometry (direct method) in patients with low platelet counts.

\section{METHODS}

From January of 1997 through March of 2004, a total of 15100 patients were referred to the CHSP because of blood disorders (anemia, leucopenia, thrombocytopenia, clotting changes, adenomegaly, leukemia and others). The cases referred for low platelet counts were identified and included in this study.

According to the thrombocytopenia diagnosis, the patients were divided into two groups: Idiopathic Thrombocytopenic Purpura (ITP) and Other Thrombocytopenia, including the normal low range, cause to be established, hepatitis $\mathrm{C}$ virus (HCV) infection, HIV, hypersplenism, EDTA-PTCP artifact, laboratory errors and other causes. The low platelet count group called "normal range" was so defined because of platelet counts between 120000 and 150000/ $\mathrm{mm}^{3}$, and no other clinical or laboratorial change was found in these patients, during a 8-year follow-up.

Flow cytometry immunophenotyping (direct method) was used to identify the antiplatelet antibody.

Platelets were counted by the Coulter T-890 device, in EDTA K3 and sodium citrate, and recounted after 24 hours at $4^{\circ} \mathrm{C}$, manual counting by the Fonio method and in the Neubauer chamber. Bone marrow tests were carried out by conventional techniques. The biochemical and serological tests were performed using the Cobas Core device (Roche). Moreover, a Coulter Epics XLMCL cytometer was employed, in addition to CD41 PE (Immunotech) and anti-Human IgG FITC conjugate (SIGMA) to identify the antiplatelet antibodies.

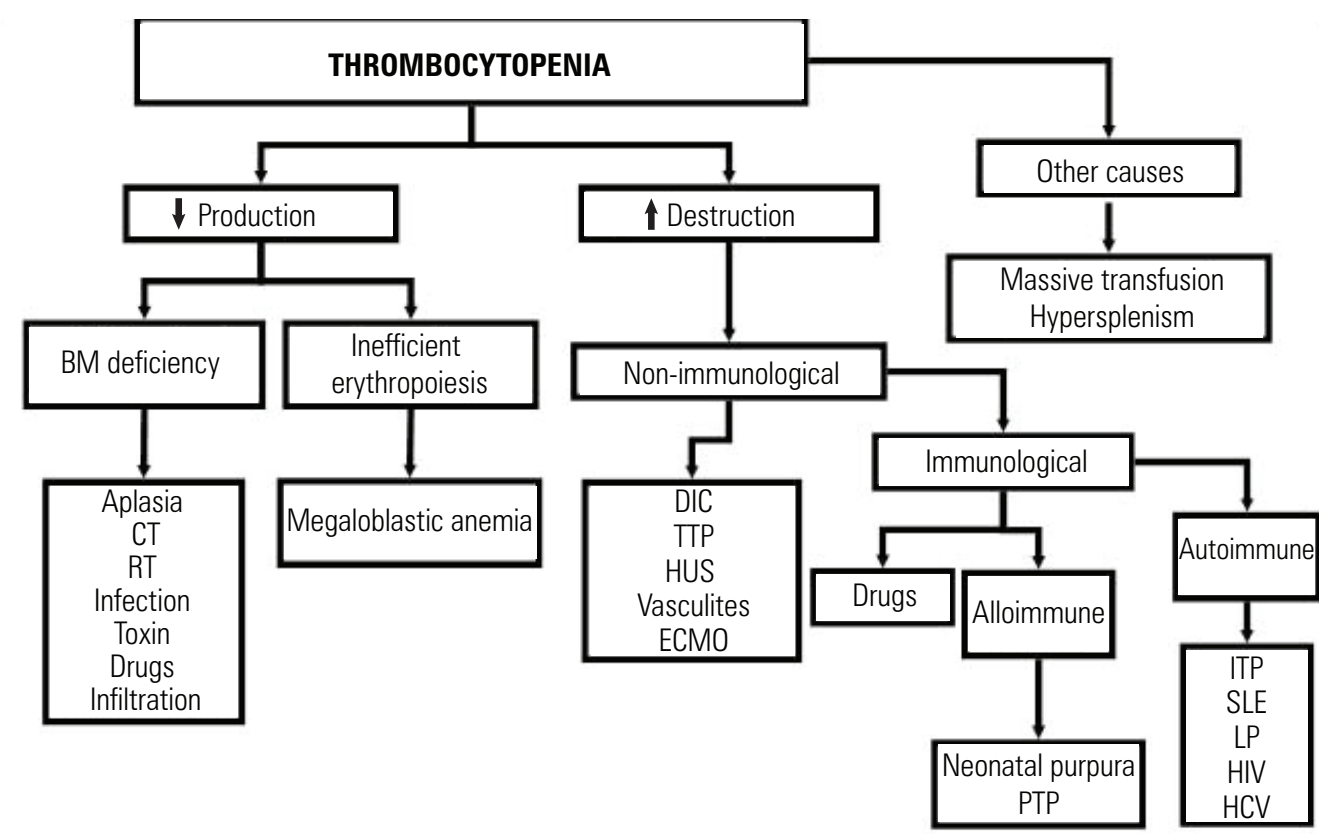

$\mathrm{BM}=$ bone marrow, $\mathrm{CT}=$ chemotherapy, $\mathrm{RT}=$ radiation therapy, $\mathrm{DIC}=$ disseminated intravascular coagulation, TTP $=$ thrombotic thrombocytopenic purpura, HUS $=$ hemolytic uremic syndrome, ECMO = extracorporeal membrane oxygenation, PTP = post-transfusional purpura, ITP = idiopathic thrombocytopenic purpura, SLE = systemic lupus erythematosus, LP = lymphoproliferative diseases, HIV = human immunodeficiency virus, HCV = hepatitis $\mathrm{C}$ virus

Figure 1. Causes of thrombocytopenia 


\section{RESULTS}

Of all cases, 1057 (7\%) were referred because of low platelet counts, and of these, 670 were females (63.4\%). Age varied between 1 and 75 years (Figures 2 and 3).

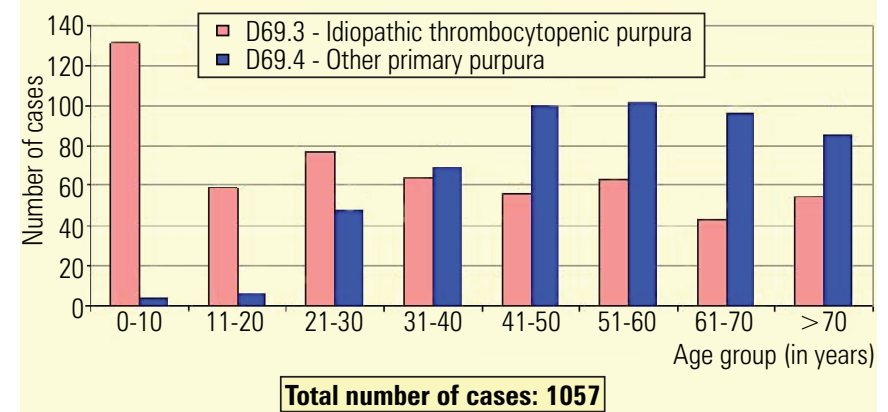

Source: Centro de Hematologia de São Paulo

Figure 2. Distribution of patients per age and condition (CHSP, January 1997 to March 2004)

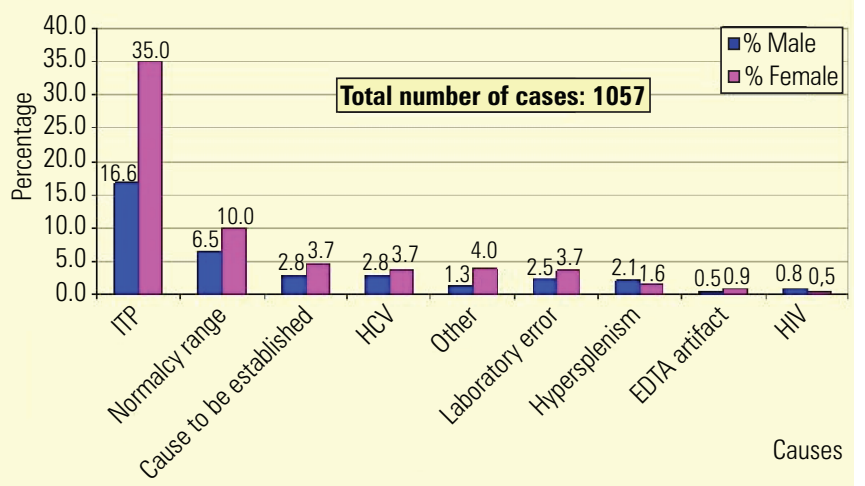

Source: Centro de Hematologia de São Paulo

Figure 3. Distribution of causes per sex (CHSP, January 1997 to March 2004)

ITP was found in $52 \%$ of the thrombocytopenia cases, being more frequent in females, children and young adults. $\mathrm{HCV}$ was prevalent in $7 \%$ and $\mathrm{HIV}$ in $1 \%$ of the cases. Normal ranges were observed in 17\%; laboratory error in 6\%; and laboratory artifact in $1 \%$ of the cases. Figures 4 and 5 depict the percentage of disease causes which led these patients to the CHSP.

Flow cytometry immunophenotyping was carried out in 115 cases $(9.7 \%)$ to identify the antiplatelet antibody (direct method), and it was positive in $40 \%$ of cases, negative in 55\% and dubious in 5\% (Figures 6, 7 and 8).

The antiplatelet antibody was positive in $76.9 \%$ of the ITP cases; and negative in $83.3 \%$ of the normal range cases (Figures 6,7 and 8).

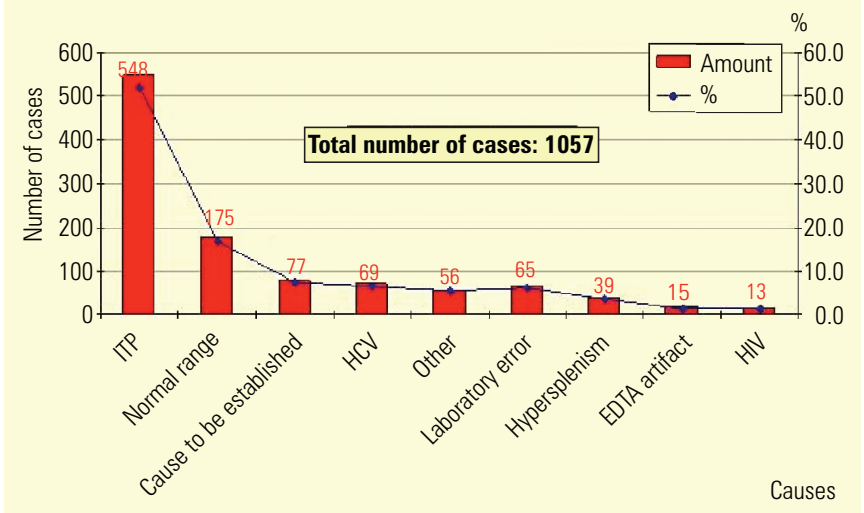

Source: Centro de Hematologia de São Paulo

Figure 4. Distribution of causes of diseases (CHSP, January 1997 to March 2004)

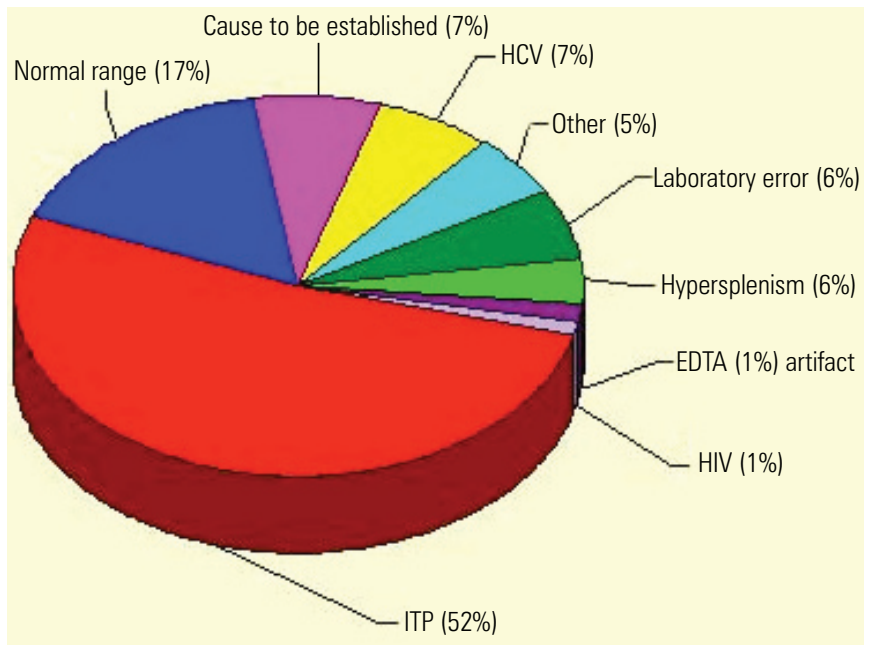

Total number of cases $=1057$

Source: Centro de Hematologia de São Paulo

Figure 5. Percentage of causes of diseases (CHSP, January 1997 to March 2004)

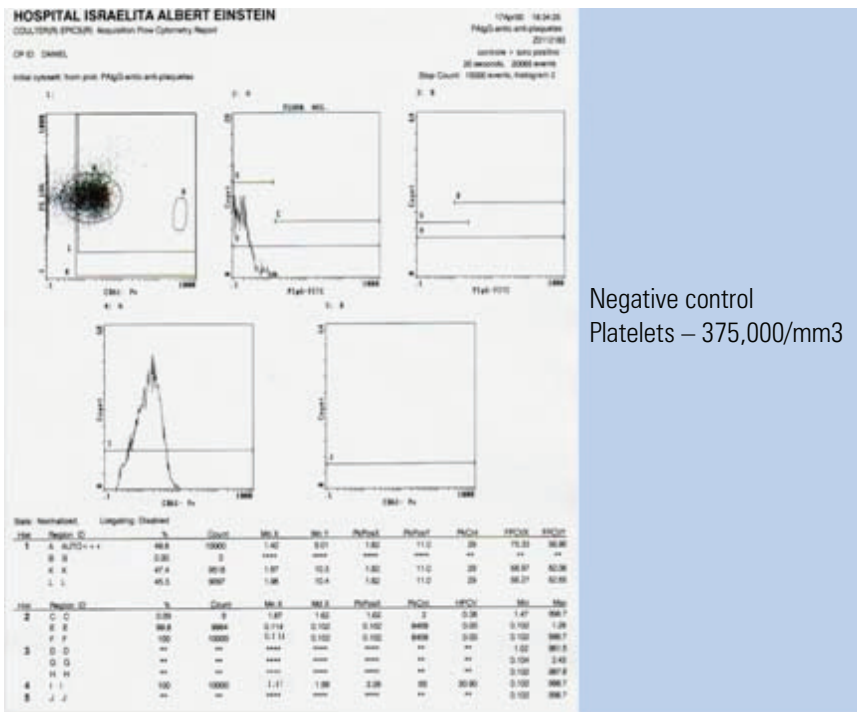

Figure 6. Flow cytometry immunophenotyping 


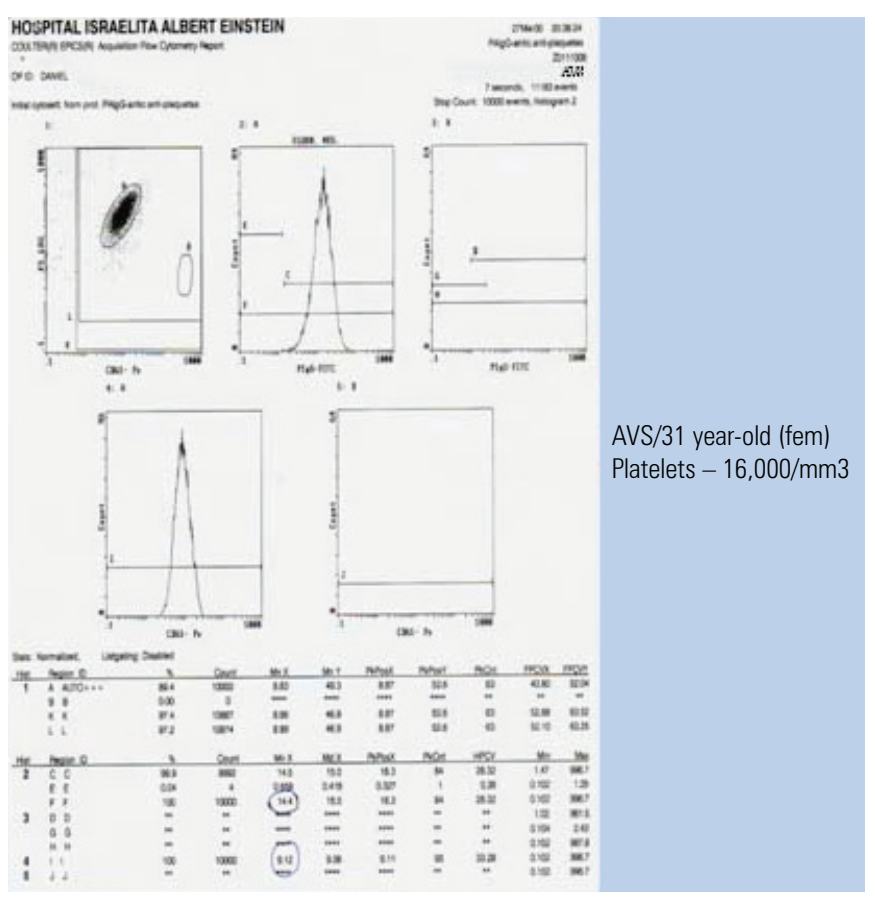

Figure 7. Flow cytometry immunophenotyping

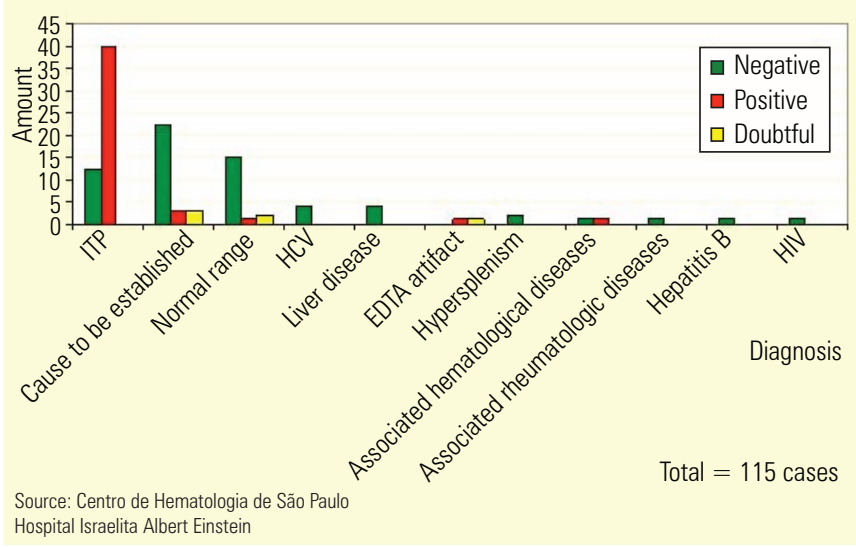

Figure 8. Distribution per diagnosis and result (CHSP/HIAE, January 1997 to March 2004)

\section{DISCUSSION}

Thrombocytopenia is a frequent laboratory finding. In the present study, ITP was the most common cause of thrombocytopenia, more frequently among females, in children aged 1 to 10 years and young adults between 15 and 40 years, according to the literature ${ }^{(2-4)}$.

In the present study, the low normal range was the second largest cause of low platelet counts, which makes us challenge the normal values of platelet counts used by most laboratories using automatic platelet counting. There is no population study in this field focused on reference values.
The microscopic analysis of the dry smear, without anticoagulant, was important to identify PTCP, macro platelets and morphological changes in the hematopoietic lineages ${ }^{(3-5)}$.

The antiplatelet antibody was a useful test, when positive, to confirm ITP; and it was also important, when negative, to rule out wrong diagnoses of low platelet counts, as is the case of dealing with the low normal range ${ }^{(6,7)}$.

Immune thrombocytopenia is a diagnosis of exclusion. This study may shed some light and indicate the laboratory tests that must be ordered to clarify the etiology, final diagnosis and management.

For the antiplatelet antibody test performed in the present study, the direct method by flow cytometry was used to identify the immunoglobulin $\mathrm{G}$ ( $\mathrm{IgG}$ ) bound to the platelet membrane. There is another test available, represented by a pool of antibodies - IgA, IgM and IgG (indirect method), which can be ordered when one suspects of an immune cause. The fact of having used only one test to investigate antiplatelet antibody may explain the $20 \%$ negative results in ITP cases, and for these patients only an immune cause by the $\operatorname{IgG}$ antibody could be ruled out ${ }^{(6-9)}$.

Thrombocytopenia is a frequent laboratory finding and implies a correct investigation of its possible causes, which is fundamental to avoid misdiagnoses and inadequate treatments. For successful diagnosis, it is very important that the assistant physician work together and share information with the clinical laboratory.

\section{CONCLUSION}

The antiplatelet antibody is a useful test, when positive, to confirm the diagnosis of idiopathic thrombocytopenic purpura, and very important, when negative, to rule out misdiagnoses.

In the daily practice the antiplatelet antibody must not be routinely ordered; it is needed for cases of low platelet counts when the assisting physician needs investigate more about an immune cause.

\section{REFERENCES}

1. Lee RG, Foerster J, Lukens J, Paraskevas F, Greer JP, Rodgers GM, et al . Wintrobe's clinical hematology. 10a ed. New York: Williams \& Wilkins; 1999. p.1579-82.

2. Lombarts AJ, Zijlstra JJ, Peters RH, Thomasson CG, Franck PF. Accurate platelet counting in an insidious case of pseudothrombocytopenia. Clin Chem Lab Med. 1999;37(11-12):1063-6.

3. Ahn HL, Jo Yl, Choi YS, Lee JY, Lee HW, Kim SR, et al. EDTA-dependent pseudothrombocytopenia confirmed by supplementation of kanamycin; a case report. Korean J Intern Med. 2002;17(1): 65-8. 
4. Schrezenmeier H, Müller H, Gunsilius E, Heimpel H, Seifried E. Anticoagulantinduced pseudothrombocytopenia and pseudoleucocytosis. Thromb Haemost. 1995;73(3):506-13.

5. McMillan R. The pathogenesis of chronic immune (idiopathic) trombocytopenic purpura. Semin Hematol. 2000;37(1 Suppl 1): 5-9.

6. Fabris F, Scandellari R, Randi ML, Carraro G, Luzzatto G, Girolami A. Attempt to improve the diagnosis of immune thrombocytopenia by combined use of two different platelet autoantibodies assays (PAlgGand MACE). Haematologica. 2002;87(10):1046-52.
7. Latorraca A, Lanza F, Moretti S, Ferrari L, Reverberi R, Galluccio L, et al. Flow cytometric analysis of anti-platelet antibodies in idiopathic thrombocytopenic purpura. Haematologica. 1994;79(3):269-72.

8. British Committee for Standards in Haematology General Haematology Task Force. Guidelines for the investigation and management of idiopathic thrombocytopenic purpura in adults, children and in pregnancy. Br J Haematol. 2003;120(4):574-96.

9. Tomer A. Flow cytometry for the diagnosis of autoimmune thrombocytopenia. Curr Hematol Rep. 2006;5(1):64-9. 